UDC 811.113.6

\title{
Iwona Kowal
}

Jagellonska universitetet $i$ Krakow, Polen

\section{SATSADVERBIAL I SVENSKUNDERVISNINGEN - EN LÄROBOKSANALYS}

For citation: Kowal I. Satsadverbial i svenskundervisningen - en läroboksanalys. Scandinavian Philology, 2020, vol. 18, issue 1, pp. 56-71. https://doi.org/10.21638/11701/spbu21.2020.104

I detta bidrag presenteras en analys av en lärobok i svenska som främmandespråk med särskilt fokus på information om satsadverbial. Utgångspunkten till analysen var Krashens inputhypotes som säger att utveckling av språkfärdigheter i andraspråket kräver ett tidigare språkligt inflöde som är ett steg högre än den nivå på vilken inläraren befinner sig. Analysen omfattade läroboken Rivstart B1 +B2 - både textboken och övningsboken. Undersökningen fokuserade på användning av olika betydelsegrupper av satsadverbial samt dessas placering i satsen (huvudsatsen och bisatsen) eftersom den svenska ordföljden kräver olika position av satsadverbial, beroende på satstyp. Dessutom undersöktes explicit och implicit förekomst av satsadverbial i båda böcker. Analysen visade att både textboken och övningsboken innehåller flera olika satsadverbial. Den explicita användningen var mer frekvent $\mathrm{i}$ övningsboken än i textboken, men tyngdpunkten låg alltid på adverbialens betydelse och användningsområde och inte syntaktiska position. Den implicita användningen däremot kunde oftare hittas i textboken än i övningsboken. Dessutom förekom det en betydande diskrepans i fördelningen av satsadverbial i huvudsatser och bisatser. Satsadverbial presenterades nästan bara i huvudsatser - inlärare får alltså ett mycket begränsat inflöde av dessa led i bisatskonstruktioner vilket leder till en stark underrepresentation av preverbal position av satsadverbial i bisatser i svenska.

Nyckelord: satsadverbial, läroboksanalys, svenska som främmandespråk, språkligt inflöde.

\section{INLEDNING}

Språkinlärning är en komplex process där olika faktorer samspelar med varandra. Vissa av dem är oumbärliga för att språket överhuvudtaget ska kunna utvecklas hos individen medan andra hellre har en 
stödfunktion och fungerar som en katalysator, dvs. påverkar inlärningstempo eller-omfång. Till de nödvändiga faktorerna hör utan tvivel språkligt inflöde (eller input) som inläraren får genom olika kanaler. När språkinlärningen sker i naturlig miljö kommer inflödet nästan hela tiden och det omfattar olika domäner. Man kan till exempel höra privata samtal när man åker buss, lyssna på politiska eller yrkesrelaterade diskussioner på arbetsplatsen eller titta på vetenskapliga program när man sitter hemma framför teven. Situationen ser dock annorlunda ut när man lär sig språket i klassrumsmiljön där man har tillgång till det några timmar i veckan och där inflödets art och mängd i hög grad styrs av läraren och/eller läromaterial. Krashen [1976] hävdar till och med att man genom dessa två olika inlärningssituationer (alltså den naturliga och den styrda) får olika typer av kunskaper i andraspråket. Inlärning eller tillägnande, som han explicit uttrycker, som sker i den naturliga miljön resulterar i omedvetna språkkunskaper som liknar de kunskaper som barn får i modersmålet: man kan alltså använda språket utan att kunna förklara varför en specifik konstruktion eller ett specifikt uttryck är korrekt eller inte. Språkinlärning i klassrumsmiljön leder å andra sidan till utveckling av explicita språkkunskaper där inläraren känner till principerna för språkanvändning, kan förklara dem och skapa nya yttranden i vilka dessa principer används medvetet. Varje textproduktion förutsätter dock en tidigare input vars form och kvalitet är av avgörande betydelse för framtida utveckling. I utvecklingspsykologin hänvisas i detta sammanhang till Vygotskys teori om den närmaste utvecklingszonen (eng. zone of proximal development) som säger att inläraren inte själv kan utföra en uppgift utan den behöver någon som kan ge stöd åt den. Och genom detta stöd kan zonen utvidgas så att nya uppgifter blir möjliga att utföras [Vygotsky, 1962]. I andraspråksinlärningen hänvisas ofta till en annan studie av Krashen [Krashen, 1987] där han påpekar att inte varje inflöde garanterar att inläraren gör framsteg i språket. För det första ska det inkommande språkmaterialet vara förstått av eleven och för det andra måste det vara på en högre nivå (ett steg högre, som Krashen hävdar) än den nivå på vilken andraspråksinläraren befinner sig. Viktigast är dock att inte alla strukturer behöver vara förstådda utan att hela budskapet kan förstås även om det innehåller en ny struktur eller ett nytt uttryck [Krashen, 1987]. Det innebär alltså att när man kommunicerar med inläraren - oberoende om det handlar om talat språk eller om skrivet 
undervisningsmaterial - behöver man inte nödvändigtvis fokusera på vad inläraren redan kan utan man kan gärna fläta in någonting som är okänt och det är just det okända som kan påverka framsteg i språkinlärningen. Denna hypotes har delvis kritiserats av andra forskare som ansåg att det inte går att fastställa vad som kan vara denna $i+1$-nivå och hur läraren kan kommunicera med inlärarna så att dessa verkligen får det språkliga inflöde som endast är lite mer avancerat än det de hittills fått. Grundtanken som ligger bakom denna hypotes är dock att inte ge för mycket ny information som kan leda till missuppfattning av budskapet och samtidigt inte leverera ett inflöde som är på samma nivå och separat ge explicit information om någonting som är nytt för inläraren.

Denna tanke har bl.a. lett till utveckling av en kognitivt baserad teori, s. k. processbarhetsteori som anger att inläraren endast kan producera sådana yttranden som den kan processa. Alltså även om man får mycket input innebär det inte automatiskt att den kan användas i elevens språkliga produktion. Processbarhetsteorin förutsätter att inläraren går igenom specifika steg i utvecklingen av andraspråket. Dessa steg omfattar språkets morfologiska och syntaktiska dimensioner. På det första steget producerar eleven enstaka ord som inte enhetligt böjs och som bara följer efter varandra. Det andra steget kännetecknas av att inläraren kan böja ord, till exempel skapa pluralform av substantiv eller preteritumform av verb. Ordföljden är kanonisk, dvs. subjektet förekommer först och sedan kommer predikatet. På det tredje steget kan man processa ord på frasnivå, vilket återspeglas i korrekt kongruensböjning av adjektiv i attributiv funktion (t. ex. en stor hund, den stora hunden). Här brukar inlärarna ibland börja satsen med ett annat led än subjektet (oftast adverbial), men ordföljden är fortfarande rak, dvs. subjektet kommer före predikatet. Det färde steget innebär förmågan att processa information på satsnivå så att man kan ha kongruens med predikativa led i satsen (alltså hunden är stor, hundarna är stora). På syntaktisk nivå uttrycks denna progression genom det att eleverna kan använda inversion i huvudsatser. Den mest avancerade nivån förutsätter att morfologin redan är behärskad så att utvecklingen endast sker på syntaktisk nivå. Så kan inläraren placera negationen inte före det finita verbet i bisatser och inte använda inversion i indirekta frågesatser [Håkansson, 2000].

Vid andraspråksinlärningen, alltså vid tillägnande av språket i den naturliga miljön, kan inflödet knappt styras. I främmandespråkssam- 
manhang är det dock möjligt både från lärarens och lärobokens sida. Läroböcker är nämligen ett stöd både för eleven och för läraren. Eleven får ett strukturerat inflöde som förväntas förmedla språklig information progressivt. Läraren i sin tur får ett referensverktyg som den kan stödja sig på i undervisningen eller också komplettera med egna inslag. I idealfallet ska läroboken följa inputhypotesens och processbarhetsteorins antaganden, alltså att materialet som representeras i den stegvis inför nya moment så att inläraren kan utveckla sina färdigheter i takt med sina kognitiva förmågor. Flyman Mattson genomförde en analys av tre läromedel i svenska för invandrare (Mål, Framåt och Samspråk). Utvärderingens fokus låg på grammatisk progression i läroböckernas lärandemål, dvs. de hänvisningar om progression som förekom i lärarhandledningar. Undersökningen visade att det å ena sidan fanns skillnader mellan läroböckerna angående framställning av de grammatiska målen. Å andra sidan kunde märkas att endast vissa läroböcker följde i sina beskrivningar av grammatiska moment processbarhetsteorin utvecklingssteg, dvs. att det grammatiska materialet introducerades i den ordning som motsvarar processbarhetsteorins nivåer [Flyman Mattson, 2013].

Läroböcker i främmandespråk utformas nuförtiden ofta i enlighet med Europarådets gemensamma referensram för språk (eng. Common European Framework of Reference for Languages, nedan kallat CEFR) som bl. a. anger olika deskriptorer för språkfärdigheter som är kännetecknade för en viss nivå. CEFR urskiljer tre grundläggande nivåer: A som beskriver språkanvändare på nybörjarnivå, B som hänvisar till självständiga användare och C som tillskrivs avancerade språkanvändare. Alla dessa tre nivåer delas in i undernivåer: (lägre) 1 och (högre) 2. Deskriptorerna omfattar fyra grundläggande färdigheter: muntlig produktion, skriftlig produktion, läsförståelse och hörförståelse. Eftersom denna artikel ska behandla en lärobok på B1 + B2-nivå fokuseras här på de färdigheter som endast gäller dessa nivåer. I den språkliga produktionen ska självständiga språkanvändare bl. a. producera sammanhängande texter, kommentera och förklara sina åsikter, använda (ett begränsat antal) sambandsmarkörer och ha grammatisk korrekthet på meningsnivå [CEFR, 2001]. Dessa färdigheter kan ha sina språkliga uttryck i satsadverbial, alltså ord eller flerordskonstruktioner som på något sätt modifierar ett yttrande. 


\section{SATSADVERBIAL I SVENSKAN}

Satsadverbial (eng. disjunct) är en satsdel, alltså en syntaktisk enhet som "ger varierade möjligheter till kommentar av satsens innehåll: med dem kan talaren negera satsen, visa sin attityd till satsens sanningshalt, ange hur önskvärt satsens sakförhållande är, visa satsens logiska anknytning till textomgivningen etc.” [SAG 1999, s.4]. Det har alltså ett brett användningsområde i språket och kan uttryckas med hjälp av olika konstruktioner. Svenska Akademiens grammatik urskiljer fyra betydelsegrupper hos satsadverbial: modala, konjunktionella, fokuserande och negerande. Oftast representeras denna satsdel av adverb med omständighetsbetydelse, i synnerhet adverb som uttrycker logisk relation, negation och talarattityd. Som typiska modala satsadverbial kan följande adverb anges: kanske, tydligen, naturligtvis, nog. De konjunktionella satsadverbialen representeras exempelvis av adverben därför, alltså, också, däremot, nämligen. Bland de fokuserande förekommer ofta bara, åtminstone, just, endast. De negerande satsadverbialen har adverbet inte som sin prototypiska representant, dock kan även adverben icke, ej, ingalunda förekomma i denna funktion. Dessutom kan olika flerordsuttryck förmedla dessa betydelser, som till exempel: helt säkert, till och med, $p a ̊$ grund av detta, allra minst, så att säga och flera andra. Satsadverbial har en bestämd position i satsen. Prototypiskt är det mittfältet, men även andra positioner (fundament eller annex) är möjliga för adverbialens placering. När de står i mittfältet har de dock, beroende på satstyp, olika position i förhållande till verbet. I huvudsatser förekommer de efter det finita verbet medan i bisatser står de före verbets finitform.

Satsadverbial utgör ett viktigt moment i svenskundervisningen. För det första på grund av att de hjälper att ge yttrandet en personlig prägel (genom att t.ex. uttrycka talarattityd) och därför brukar de ofta användas i argumenterande texter eller essäer. Med hjälp av satsadverbial (som i sådana fall också kallas för sambandsord) skapas dessutom kohesion i texten vilket också är en prestation i språkproduktionen. Till slut är satsadverbialen viktiga i undervisningen ur formell synpunkt. De har oftast en fast position i satsen och i andraspråkssammanhang ska denna position behärskas och automatiseras så att man kan skapa nya yttranden utan att tänka på var i satsen ledet i fråga ska hamna. Enligt processbarhetsteorin tillhör förmågan att korrekt placera satsadverbial det sista utvecklingssteget vilket innebär att tillägnande av dessa adver- 
bial kan utgöra en av de senare inlärda färdigheterna som andra- eller främmandespråkinlärare kan processa. Det kan gälla både de lexikalisk-semantiska (ordval) och de formella (korrekt placering i satsen) aspekterna i språket.

Som Andréasson påpekar är det svårt att skilja mellan form och funktion när man behandlar satsadverbial i grammatikböcker för svenska. Hon hänvisar till grammatikböcker som utgavs på 1800-talet där gränsen mellan ordklassen adverb och satsledet adverbial inte var skarp [Andréasson, 2007]. Även idag finns det inga enhetliga beskrivningar av satsadverbial i svenska grammatikböcker för andra-/främmandespråksinlärning. En del av dessa böcker gör en klar distinktion mellan satsadverb och satsadverbial där det första är en ordklass medan det andra en satsdel (som representeras av denna ordklass). I "Deskriptiv svensk grammatik" kan man påträffa satsadverb som är en funktionell undergrupp ingående i ordklassen adverb och satsadverbial som (endast) utgörs av vissa adverb vilka i detta sammanhang kallas för "vandrande adverb" där inte bara "rena" satsadverb utan även vissa tidsadverb (ofta, förr) eller sättsadverb (sakta, snabbt) tillhör [Deskriptiv svensk grammatik, 1993]. Även i "Funktionell svensk grammatik" förekommer både satsadverb och satsadverbial där den enda skillnaden beror på klassificeringen: satsadverb är en ordklass medan satsadverbial - en satsdel bestående av satsadverb [Bolander, 2005]. I "Svensk grammatik. Svenska som främmandespråk" finns det inget separat moment som behandlar satsadverb. Dessa ingår i gruppen "jakande och nekande adverb", där en tilläggskommentar kommer att vissa adverb kan förstärka eller modifiera satsen. Konjunktionella adverb beskrivs i boken som "en typ av satsadverb" även om själva gruppen satsadverb inte beskrivs eller definieras i ordklassammanhang. Satsadverb förekommer dock igen i ordföljdskapitlet där de, i likhet med Deskriptiv svensk grammatik, beskrivs som "vandrande" eller "rörliga" adverb. Det ska framhävas i detta sammanhäng att de anförda exemplen på satsadverb inte bara innehåller de populäraste och oftast uppräknade satsadverben utan även omfattar alltid och aldrig som egentligen klassificerats som tidsadverb i boken. Dessutom dyker termen satsadverbial inte alls upp. I syntaktiska sammanhang behandlas bara (sats)adverb även om det handlar om en satsdel som modifierar eller negerar satsinnehållet och även om andra led beskrivs med syntaktiska termer (subjekt, objekt, predikativ) [Lindholm, 1997]. 
Mot bakgrund av det ovannämnda kan det därför vara begrundat att analysera hur läroböcker i svenska förmedlar information om satsadverbial. För det första ska i denna artikel undersökas vad som explicit anges om satsaderbial, alltså vilken direkt input inläraren får i läroböcker i svenska. Dessutom ska all implicit information analyseras, dvs. direkt användning av satsadverbial i läroböckernas texter eller övningar. Målet med denna studie är alltså att hitta svar på frågan om och hur läroboken kan hjälpa främmandespråksinläraren att använda en bred repertoar av satsadverbial. Med andra ord: är inflödet mångfaldigt både vad det gäller urval av ord eller uttryck och satsadverbialens syntaktiska distribution, dvs. förekomst i huvud-resp. bisatser så att man inte bara kan veta vilka satsadverbial som kan användas utan även var de ska placeras i satsen.

\section{UNDERSÖKNINGENS BESKRIVNING}

I denna studie ska en lärobok i svenska som främmandespråk analyseras, med dess två versioner: textboken och övningsboken. Den analyserade läroboken är Rivstart $B 1+B 2$ av Paula Levy Scherrer och Karl Lindemalm, utgiven 2010 av förlaget Natur och Kultur. I analysen ingick endast de ord och uttryck vars syntaktiska funktion i satsen kunde beskrivas som satsadverbial enligt den indelning som förekommer i SAG, alltså modifierare med konjunktionell, modal, fokuserande eller negerande betydelse. Både enstaka ord (satsadverb) och flerordsuttryck (fraser med satsadverbiell funktion) ingick i analysen. Bakgrunden till valet av en lärobok på B1 + B2-nivå var de anförda deskriptorerna i CEFR-skalan som antydde att eleven på B2-nivå förväntas använda olika bindeord (konjunktionella satsadverbial), argumentera och uttrycka sina personliga åsikter (alla typer av satsadverbial), och ha god grammatisk behärskning som t. ex. endast visas i "små misstag i meningsstrukturen" [CEFR 2001, s. 111]. Analysen ska därför fokusera på mångfalden av satsadverbial i läroboken samt på förhållandet mellan användning av dessa adverbial i bisatser och huvudsatser. Dessutom ska den omfatta både explicit information som gäller satsadverbial, dvs. de moment som uttryckligen behandlar satsadverbialens betydelse eller struktur, och implicit användning, dvs. förekomst av satsadverbial i läroböckernas texter och övningar utan att lägga särskilt fokus på denna satsdel. 


\section{ANALYS AV MATERIALET}

Satsadverbial förekom rätt ofta i de undersökta läroböckerna. Sammanlagt kunde 1353 uttryck i denna funktion urskiljas varav 928 förekom i textboken (nedan kallat TB) och 425 i övningsboken (nedan kalllat ÖB). Satsadverbialen presenterades och beskrevs både explicit och implicit i båda delar av undervisningsmaterialet.

I textboken nämns satsadverbialen uttryckligen både med hänsyn till deras betydelse och placering i satsen. Vad det gäller adverbialens betydelse förekommer det tre moment i textboken där dessa led får en framhävd position. Totalt handlar det om sådana adverbial som: nämligen, dock, därför, däremot, väl, nog, alltså, typ och liksom. I det första momentet kalllas de för sambandsord, i det andra: satsadverb och i det tredje: småord i talspråk. I alla dessa tre fall gulmarkeras de i texten och efteråt följer oftast en övning som fokuserar på semantiskt korrekt användning av dessa ord. Placering i satsen förklaras inte, dock i varje fall förekommer dessa adverbial i huvudsatser i sin prototypiska mittfältsposition.

Två gånger framhävs satsadverbialens position i satsen, dock även här är det endast huvudsatser som anges som exempel. Dessutom står det inte i texten att det handlar om adverbial utan i allmänhet om "ord i svenskan som man inte kan ha först i en mening” [TB, s. 46]. Här räknas bl. a. också och förstås och rekommenderas vilka ord som i stället kan ta denna fundamentposition (dessutom, naturligtvis, självklart). Eftersom momentet inte bara handlar om satsadverbial innehåller det även konjunktioner som därför att och eftersom. Nästa gång förekommer satsadverbial uttryckligen i grammatiska sammanhang i kapitlet med namnet "Minigrammatik" [s.225]. Där presenteras ordföljd i huvudsatser och bisatser med alla positioner markerade. Positionen i fråga heter "satsadverb” och i huvudsatsordföljden representeras den av två ord: kanske och aldrig medan i bisatsordföljden anges det alltid och inte. Det är viktigt att påpeka att både aldrig och alltid egentligen är tidsadverb men de nämns ofta bland s. k. vandrande adverb vilket leder till att de kanske blir uppfattade som satsadverbial. Den funktionella faktorn, alltså mittfältspositionen tycks leda till en automatisk klassificering av dessa ord som satsadverb(ial).

I övningsboken förekommer explicita uppgifter om satsadverbial oftare än i textboken. Här är det dock, i motsats till textboken, betydelsen som oftare framhävs. Ordet satsadverbial förekommer inte en enda 
gång, i stället för detta kan man hitta begreppen satsadverb och sambandsord. Även i övningsboken gulmarkeras de tematiska orden (nämligen, dock, därför, däremot) och det kommer en kommentar att de kan uttrycka kontrast eller förklaring. Dessutom anges en kort information att man inte ska börja satsen med dock eller nämligen. I varje exempel förekommer adverben i huvudsatsen. Ett moment i övningsboken behandlar satsadverbet $j u$ där ordets användningsområde beskrivs och inläraren får till uppgift att sätta in adverbet där det passar. Uppgiften gäller alltså både innehållssidan (att placera ordet i rätt kontext) och den strukturella sidan (att sätta in adverbet på rätt plats i satsen). Dessutom presenteras satsadverb än en gång i övningsboken. I detta fall är det tre adverb: väl, nog och $j u$ - igen med fokus på deras användningsområde. Övningarna som följer efter förklaringarna hänvisar även i detta fall till adverbens semantiska aspekter. Endast en gång framhävs satsadverbens position i satsen. I övningsboken finns igen samma tabell som i textboken [s. 17] med satspositionerna uppräknade där alltid och inte nämns som satsadverb. Dessutom anges en explicit information: "I bisats kommer satsadverbet före första verbet." [ÖT, s. 17] Även om denna information förekommer får eleven en övningstext där hen ska stryka under alla bisatser - men i ingen av dem används satsadverbial. Alla placeras i huvudsatser i stället.

Vad det gäller explicit beskrivning av satsadverbial i textboken och övningsboken kan alltså konstateras att båda böcker innehåller framför allt information om adverbialens användning i texten. Satsadverbialens position i satsen får bara lite plats i båda böcker. Alla exempel som anförs presenterar denna satsdel i huvudsatser — oftast i mittfältet, endast i några få fall i fundamentet.

Medan satsadverbial endast förekommer några få gånger i de explicita beskrivningarna presenteras de implicit mycket ofta i läroböckernas texter och övningar. Det mest frekventa satsadverbialet är det negerande inte som utgör $53 \%$ av alla uttryck i denna funktion. Både i textboken och övningsboken finns det flera meningar där inte används. Negationen används både i textstyckena $(1,2)$ och i övningarna $(3,4)$.

1. Men någon simhall hade man inte så man fick simma $i$ ån som flyter genom Uppsala [TB, s. 14].

2. Förra veckan skulle jag gå en jobbintervju och jag visste inte hur jag skulle klä mig. [ÖB, s. 18]. 
3. Mia ville inte hålla på med politik därför att:

a) Hennes föräldrar var ointresserade av politik.

b) Hon hade lyssnat på för mycket prat om politik hemma.

c) Mias föräldrar protesterade mot hennes politiska intresse [TB, s. 63].

4. Bry dig inte att han luktar [ÖB, s. 20].

I några få fall fanns negerande uttryck med inte som tillsammans med ett annat ord bildade ett flerordigt satsadverbial, oftast med bara eller alls, fast det förekom även andra konstruktioner (inte ens, inte riktigt).

5. Det är inte bara de traditionella helgdagarna som är viktiga [TB, s. 147].

6. En del verb ska inte användas alls, en del ska användas flera gånger [ÖB, s. 125].

7. Hon kunde inte ens en snigel utan att stanna och kolla att den mådde bra [ÖB, s. 37].

8. X skriver att... men det kan jag inte riktigt hålla med om [TB s. 137].

De övriga betydelsegrupperna är också bra representerade i undervisningsmaterialet. Konjunktionella och modala satsadverbial är fördelade ganska ojämnt i läroböckerna. Medan det förekommer 16 olika konjunktionella adverbial finns det nästan dubbelt som många modala modifierare. Bland de konjunktionella adverbialen används också, nämligen, därför, $i$ stället, däremot och alltså oftast. De utgör $90 \%$ av alla förekomster av sambandsuttryck i bägge läroböcker. Det finns dock ett antal adverbial som inte är så frekventa i det analyserade materialet men som kan nämnas i det här sammanhanget, t. ex. annars, dessutom eller på grund av det.

9. Det är viktigt att vara snäll mot tomten för annars flyttar han till granngården [TB, s. 145].

10. Dessutom ökar trivseln och gruppkänslan bland personalen [TB, s. 206].

11. De har därför mindre erfarenhet och risken finns att de på grund av det sorteras bort i rekryteringsprocessen [TB, s. 209].

Bland de modala satsadverbialen är kanske, ju, väl, nog, verkligen, faktiskt, egentligen, tyvärr, förstå, absolut, självklart och troligtvis mest 


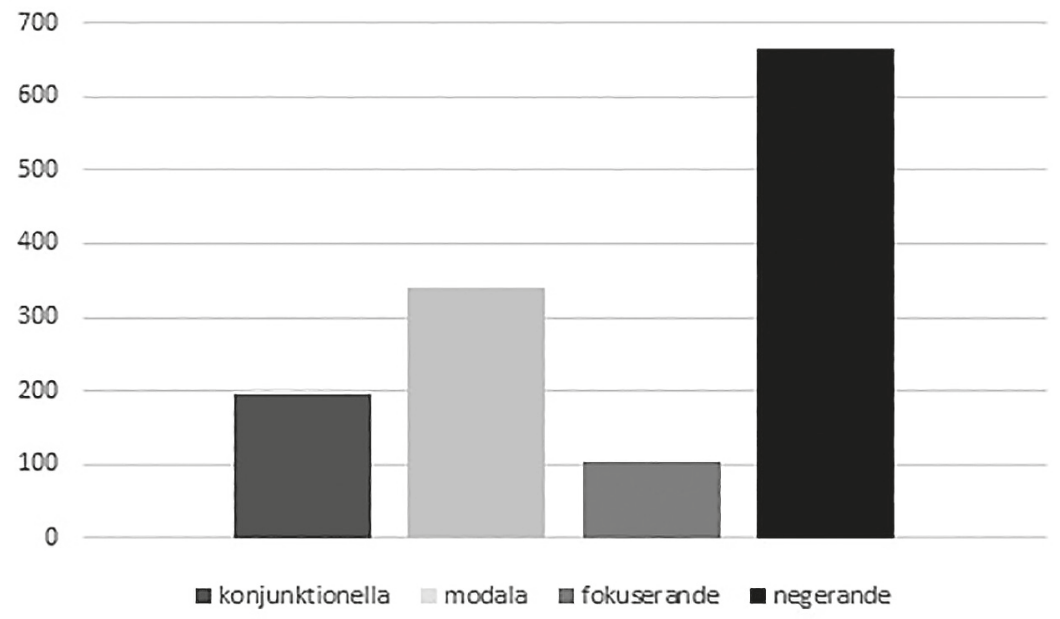

Fig. 1. Frekvens av satsadverbialen (både TB och ÖB)

frekventa och omfattar $91 \%$ av alla förekomster av modala satsadverbial. I denna grupp förekommer det dessutom en rad flerordsuttryck som t. ex.

12. Som tur var vände björnen och lufsade därifrån [ÖB, s. 81].

13. Den innebär i princip att man förutsätter att alla ens prestationer kommer att sluta i katastrof [TB, s. 161].

14. var söt och god $i$ alla fall [ÖB, s. 90].

15. Fönstren är smutsiga och toaletten är minst sagt ofräsch [TB, s. 178].

Fokuserande satsadverbial utgör den minst frekventa och minst mångfaldiga gruppen. Oftast används bara, till exempel, bland annat och även. Andra satsadverbial som främst, just eller exempelvis nämns bara några gånger.

Som det framgår av diagrammet (Fig. 1) och som tidigare nämnts får användarna av Rivstart B1+B2 oftast input med satsadverbial genom negationen inte som var den enda representanten av negerande modifierare. De modala adverbialen i sin tur är inte bara mest mångfaldiga utan även brett representerade i läroböckerna: både i textboken och i övningsboken. Från läroboksanalysen framgick det dessutom att det oftare var i textböckerna som satsadverbialen förekom. Detta kan ha 
sin förklaring i att textboken, hellre än övningsboken, innehåller längre texter som har en personlig karaktär och som ska vara välutformade genom bl.a. användning av sambandsord. I övningsboken sätts fokus på kortare sekvenser, det finns många övningar som består av lösta satser och därför kan det vara helt normalt att satsadverbial inte förekommer lika ofta som i textboken.

Den analyserade läroboken ska förmedla kunskaper som motsvarar nivå B2 enligt Europarådets referensramverk för språk. Ett av elementen som inläraren förväntas ha behärskat på denna nivå är grammatisk korrekthet i meningsbyggnaden som bl.a. kommer till uttryck i korrekt ordföljd. Satsadverbial är därför mycket viktiga i detta sammanhang eftersom de har olika position i förhållande till det finita verbet, beroende på satstyp. I huvudsatser förekommer de efter och i bisatser före det finita verbet. Analysen av de explicita uppgifterna i Rivstart visade att det bara fanns lite information om satsadverbialens position i satsen och att även om det uttryckligen påpekades i texten att bisatsen kräver en preverbal position av satsadverbialen så förekom dessa endast i huvudsatser. Analysen av implicit förekomst av satsadverbial i Rivstart bekräftade detta resultat. Även om bisatskonstruktioner med satsadverbial förekom i undervisningsmaterialet utgjorde de en liten andel av alla exempel. Genomsnittligt användes var femte satsadverbial i bisatser. När man dock tittar på dessa data individuellt för varje adverbial dyker en annan bild upp (se Figur 2 nedan).

Det finns nämligen bara tre adverbial (inte, bara och faktiskt) bland de mest frekventa ${ }^{1}$ där förhållandet mellan förekomsten i huvud- och bisatser ligger nära medelvärdet. Alla övriga populära satsadverbial kunde bara påträffas ryckvis i bisatser. Generellt är alltså diskrepansen mellan placeringen i huvud-och bisatser slående. Till följd av detta får eleven ett mycket begränsat inflöde med adverbial i bisatsordföljden vilket med stor sannolikhet kan leda till att den inte kan tillägna sig denna konstruktion. Denna diskrepans är ännu mer synlig vid jämförelse av två boktyper. Det är nämligen först och främst i textboken som satsadverbial förekommer i bisatser. Skulle man betrakta övningsboken separat kunde man knappt tro att satsadverbial överhuvudtaget kan inta en plats i bisatser. I övningsboken får man alltså explicit information att

${ }^{1}$ Som mest frekventa satsadverbial räknas här sådana adverbial som minst förekom 20 gånger i undersökningsmaterialet. 


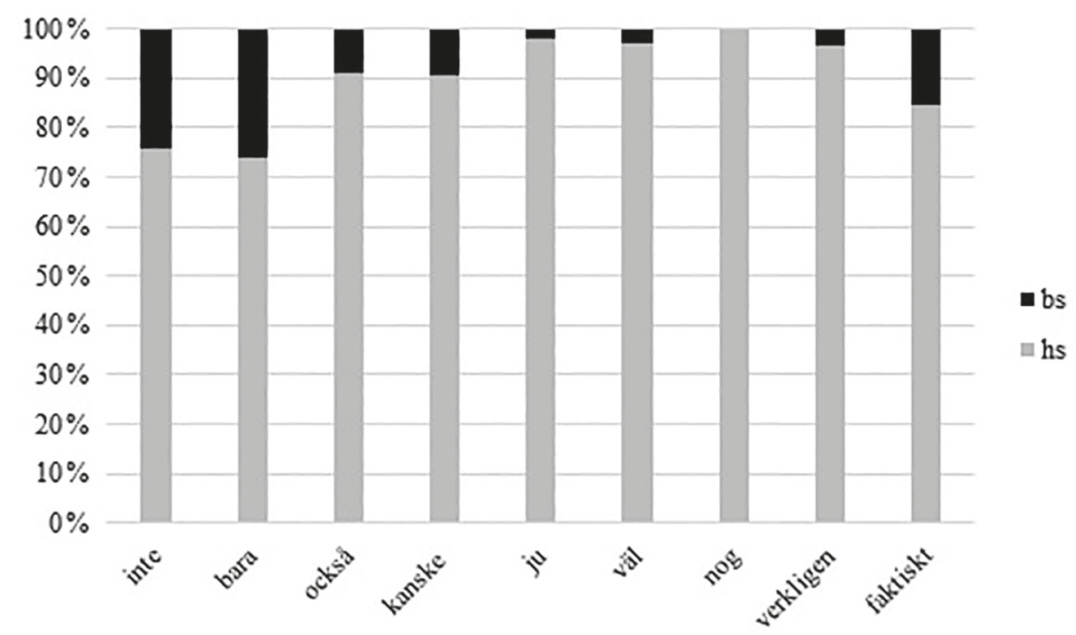

Fig. 2. Förekomst av de vanligaste satsadverbialen i bisatser (bs) respektive huvudsatser (hs)

satsadverbial både kan förekomma i huvud- och bisatser men det realiseras nästan inte alls i det löpande övningsmaterialet.

\section{DISKUSSION OCH SLUTSATSER}

Det övergripande syftet med denna studie var att hitta svar på frågan ifall och hur en lärobok i svenska som främmandespråk kan hjälpa inläraren att använda en bred repertoar av satsadverbial. För att kunna besvara denna fråga har två kompletterande läroböcker använts: en textbok och en övningsbok på B1 + B2-nivå. Analysen har visat att satsadverbial förekommer rätt ofta i det undersökta materialet vilket kan vara en bra förutsättning för tillägnande av detta satsled i svenskan. Benämningen i Rivstart lyder dock aldrig satsadverbial utan satsadverb, sambandsord och ibland även småord så den följer hellre ordklassbeskrivningen än satsledsklassificeringen. Adverbialen presenteras både explicit och implicit. Den explicita presentationen är dock mer framträdande i övningsboken än i textboken. Tyngdpunkten läggs dock i de flesta fall på adverbens betydelse och användningsområde och inte på dessas placering i satsen. Även vid explicita förklaringar om preverbal 
position i bisatser kommer inga exempelmeningar där inläraren direkt kan se och öva sådana konstruktioner.

Vid fri förekomst i läroböckernas texter och övningar kunde märkas att inläraren får en bred repertoar av satsadverbial. Alla betydelsegrupper var representerade, med det negerande inte som var det mest frekventa satsadverbiella uttrycket. Rivstart erbjuder ett stort urval av först och främst modala och konjunktionella adverbial, men även fokuserande adverbial förekommer. De populäraste adverbialen är, utom inte, de modala kanske, ju, väl, verkligen, nog och faktiskt, den konjunktionella också samt den fokuserande bara. Utom ettordsadverbialen kan inläraren också få input av flerordsuttryck som t.ex. som sagt, inte riktigt, som tur var eller $i$ alla fall. Vad det gäller omfånget kan det utom tvivel konstateras att eleven får ett mångfaldigt inflöde av satsadverbial som inte bara är de populäraste som brukar förekomma i de flesta grammatikböcker utan också de mindre frekventa. Jämfört med betydelseaspekterna behandlas den formella sidan av satsadverbial i betydande mindre omfång. Den övervägande majoriteten av satsadverbial förekommer i huvudsatser, de presenteras alltså i enlighet med processbarhetsteorins fjärde nivå. Endast inte, bara och faktiskt har en viss andel av bisatser (20-25\%) i texterna. De övriga satsadverbialen förekommer nästan alltid i huvudsatser. Denna tendens är särskilt synlig i övningsboken där bisatsordföljden egentligen är frånvarande. Och här menas inte explicit förklaring av satsadverbialens position utan direkt användning i det presenterade språkmaterialet.

Det ska alltså konstateras att det finns en stor diskrepans i inputens kvantitet och kvalitet med hänsyn till satsadverbialens betydelse/användningsområde och formella aspekter. Inflödet fokuserar egentligen på betydelsen medan adverbialens användning i olika satskonstruktioner träder i bakgrunden. Endast de populäraste satsadverben som oftast dyker upp som prototypiska (inte, bara) i olika grammatiskböcker blir synliga i olika strukturella sammanhang. Denna studie har alltså visat att det finns en viss brist i förmedlingen av satsadverbialens egenskaper och särdrag till svenskinlärare. Självklart är det inte bara läroböcker som är avgörande för inflödet. Eleven har sin lärare till förfogandet och dessutom kan den använda sig av andra källor, som t. ex. internet eller privata kontakter med svensktalande. Konstaterandet kan dessutom inte förbli utan förbehåll. För att kunna bedöma om inflödet verkligen inte motsvarar den nivå som förväntas av eleven på B2-nivån ska en 
analys av elevtexter genomföras där både användning och placering av satsadverbial analyseras och sedan sammanställs med resultaten av denna studie.

\section{REFERENCES}

Andreasson M. Satsadverbial, ledfoljd och informationsdynamik i svenskan. Goteborg: Goteborgs studier i nordisk sprakvetenskap 7, 2007. $305 \mathrm{~s}$.

Bolander M. Funktionell svensk grammatik. Stockholm: Liber, 2005. $236 \mathrm{~s}$.

CEFR. Gemensam europeisk referensram för språk: lärande, undervisning och bedömning. Strasbourg: Enheten för moderna språk, 2001. $252 \mathrm{~s}$.

Flyman Mattson A. Språklig progression i läromedel för SfI. Språk i undervisning. Rapport från ASLA:s vårsymposium, Linköping, 11-12 maj 2012. Linköping/ Växjö, ASLA, Svenska föreningen för språkvetenskap. 2013. S. 151-160.

Holm B., Nylund E., Nylund-Brodda E. (Eds). Deskriptiv svensk grammatik. Stockholm: Liber, 1993. $211 \mathrm{s.}$

Håkansson G. Svenska som förstaspråk och som andraspråk. Likheter och skillnader. Svenskan i tiden - verklighet och visioner. Stockholm: HLS förlag, 2000. S. 138-155/

Krashen S. Formal and Informal Linguistic Environments in Language Acquisition and Language Learning. TESOL. 10(2), 1976. S. 157-168.

Krashen S. Principles and Practice in Second Language Acquisition. University of California: Pergamon Press Inc., 1987. $202 \mathrm{~s}$.

Levy Scherrer P., Lindemalm K. Rivstart B1 + B2. Textbok. Stockholm: Natur \& Kultur, 2008. $240 \mathrm{~s}$.

Levy Scherrer P., Lindemalm K. Rivstart B1+B2. Övningsbok. Stockholm: Natur \& Kultur, 2008. 160 s.

Lindholm H. Svensk grammatik. Svenska som främmande språk. Lund: Kursverksamhetens förlag, 1997.216 s.

SAG $=$ Svenska Akademiens grammatik. band 4. Stockholm: Norstedts Ordbok, 1999. $977 \mathrm{~s}$.

Vygotsky L. Thought and language. Cambridge: MIT Press, 1962. 168 s.

\section{Iwona Kowal}

Jagiellonian University in Cracow, Poland

\section{DISJUNCTS IN TEACHING SWEDISH - A COURSEBOOK ANALYSIS}

For citation: Kowal I. Disjuncts in teaching Swedish - a coursebook analysis. Scandinavian Philology, 2020, vol. 18, issue 1, pp. 56-71.

https://doi.org/10.21638/11701/spbu21.2020.104 (In Swedish)

The article presents an analysis of a coursebook in Swedish for foreign language learners with a focus on information concerning disjuncts. Krashen's input hypothesis 
is used as a basic assumption, which states that the development of language skills in a second language anticipates an understandable input on a level that is one step higher than the learner's current level. The analysis involves the textbook and student's book Rivstart at the B1 + B2 level. In the study, a variety of disjuncts were considered as well as their position in a sentence (main clause versus subordinate clause) since Swedish word order requires different locations of this item in both clause types. In addition, the explicit and the implicit use of disjuncts were analysed in both books. The results indicated that both the textbook and the student's book use a wide span of different disjuncts. The explicit mention of disjuncts is more common in the student's book than in the textbook, but the focus is almost often on the meaning and not on the syntactic position. The implicit occurrence, on the other hand, is more frequent in the textbook than in the student's book. There is a considerable discrepancy in the use of disjuncts in main and subordinate clauses. Disjuncts occur almost only in main clauses - the learners become accustomed to a very limited input of disjuncts in subordinate clauses which causes a substantial underrepresentation of constructions with preverbal position and a disjunct in subordinate clauses in Swedish.

Keywords: disjunct, coursebook analysis, Swedish as a foreign language, language input.

\section{Iwona Kowal}

$\mathrm{PhD}$, Associate Professor, Jagiellonian University, Al. Mickiewicza 9/309, 31-112 Krakow, Poland E-mail: iwona.kowal@uj.edu.pl

Received: October 25, 2019 Accepted: April 27, 2020 